\title{
Campur Kode Pada Novel 99 Cahaya Di Langit Eropa Karya Hanum Salsabiela Rais Dan Rangga Almahendra (Kajian Sosiolinguistik)
}

\author{
Lili Yanti ${ }^{1)}$ \\ ${ }^{1)}$ Program Studi Pendidikan Bahasa dan Sastra Indonesia STKIP Singkawang \\ e-mail: liliyantiana18@gmail.com
}

\begin{abstract}
Abstrak. Penelitian ini bertujuan untuk mendeskripsikan campur kode pada novel 99 Cahaya di Langit Eropa karya Hanum Salsabiela Rais dan Rangga Almahendra yang meliputi wujud dan bentuk campur kode serta faktor-faktor terjadinya campur kode pada novel 99 Cahaya di Langit Eropa karya Hanum Salsabiela Rais dan Rangga Almahendra. Metode yang digunakan dalam penelitian ini adalah metode deskriptif, dengan bentuk penelitian kualitatif. Teknik pengumpulan data yaitu teknik langsung artinya peneliti sebagai instrumen kunci dan dibantu kartu pencatat data.Berdasarkan analisis data dalam novel 99 Cahaya di Langit Eropa karya Hanum Salsabiela Rais dan Rangga Almahendra terdapat wujud campur kode meliputi penyisipan unsur-unsur yang berwujud kata sebanyak 37 buah, frasa sebanyak 10 buah, baster sebanyak 5 buah, perulangan kata sebanyak 7 buah, dan penyisipan unsur yang berwujud idiom sebanyak 2 buah. Bentuk campur kode yaitu bentuk ke dalam dan bentuk ke luar. Terjadinyacampurkodedisebabkanolehbeberapafaktor yaitu tempat dan waktu terjadinya sebuah tuturan (settings), peserta tutur (participants), tujuan dari suatu peristiwa dalam suatu masyarakat (ends), pokok tuturan (act sequences), nada tutur (keys), sarana tutur (instrumentalities), norma tutur (norms), dan jenis tutur (genre). Penelitian ini diharapkan dapat menjadi referensi bagi penelitian selanjutnya dalam bidang sosiolinguistik, khususnya kajian mengenai campur kode dalam karya sastra.
\end{abstract}

Kata Kunci: Campur Kode, Novel, Sosiolinguistik

\section{PENDAHULUAN}

Bahasa merupakan sarana komunikasi yang digunakan setiap manusia sebagai penyampai pesan. Bahasa seseorang mencerminkan budaya dan latar belakangnya. Dalam berinteraksi penutur menggunakan bahasa sesuai dengan situasi dan mitra tuturnya, maka pada keadaan tertentu penutur bisa saja menggunakan dua bahasa atau lebih. Hal ini disebabkan karena masyarakat Indonesia merupakan masyarakat yang bilingual atau dwibahasa, yaitu masyarakat yang menggunakan dua bahasa dalam berkomunikasi. Dengan demikian, tidak dapat dipungkiri bahwa dalam berbahasa sehari-hari selalu terdapat kemungkinan perubahan-perubahan variasi kebahasaan, penggunaan dari satu kode kebahasaan berubah ke kode yang lain, atau percampuran kode kebahasaan dalam setiap interaksi.

Peristiwa campur kode tidak hanya terjadi dalam komunikasi percakapan lisan, tetapi juga dapat terjadi pada percakapan atau dialog (bahasa lisan yang dituliskan) antartokoh dalam novel atau karya sastra lainnya. Seperti pada novel 99 Cahaya di Langit Eropa karya Hanum Salsabiela Rais dan Rangga Almahendra. Pada novel ini terdapat campur kode dalam dialog antartokoh, sehingga kemultilingualannya memengaruhi karya sastra karya Hanum Salsabiela Rais dan Rangga Almahendra.

Pemilihan novel 99Cahaya di Langit Eropa sebagai objek penelitian berdasarkan beberapa alasan. Pertama, peneliti ingin mengetahui campur kode yang digunakan oleh pengarang atau penutur melalui tokoh-tokoh dalam novel 99Cahaya di Langit Eropa karenanovel ini banyak memunculkan peristiwa campur kode diakibatkan melibatkan banyak tokoh dengan latar budaya dan pengetahuan yang berbeda-beda.Kedua, peneliti ingin mengetahui faktor apa saja yang menyebabkan terjadinya campur kode di dalam novel 99 Cahaya karya Hanum Salsabiela Rais dan Rangga Almahendra. Alasan ketiga karena novel ini merupakan kisah perjalanan yangmenginspirasi pembaca dari penyebaran Islam tentang hidup dengan cara damai, bertoleransi, serta dengan ilmu pengetahuan dan teknologi.

Novel 99 Cahaya di Langit Eropa karya Hanum Salsabiela Rais dan Rangga Almahendra merupakan novel yang dapat menginspirasi dan membangun jiwa. Berdasarkan pemaparan tersebut, peneliti tertarik untuk menganalisis peristiwa campur kode pada novel tersebut, yaitu campur kode dalam deskripsi cerita dan campur kode dialog tokoh yang meliputi penyisipan unsur yang berwujud kata, frasa, klausa, baster, kata ulang, dan ungkapan atau idiom, baik campur kode bahasa asing maupun campur kode bahasa daerah. Selain itu, peneliti juga menganalisis faktorfaktor yang menyebabkan campur kode dalam novel 99 Cahaya di Langit Eropa karya Hanum Salsabiela Rais dan Rangga Almahendra.

Berdasarkan latar belakang yang telah dikemukakan maka rumusan masalah dalam penelitian ini adalah (1) Bagaimanakah wujud dan bentuk campur kode novel 99 Cahaya di Langit Eropa karya Hanum Salsabiela Rais dan Rangga Almahendra? (2) Faktor apa saja yang menyebabkan campur kode dalam novel 99 Cahaya di Langit Eropa karya Hanum Salsabiela Rais dan Rangga Almahendra? Dengan 
tujuan penelitian yaitu (1) Mendeskripsikan wujud dan bentuk campur kode novel 99 Cahaya di Langit Eropa karya Hanum Salsabiela Rais dan Rangga Almahendra. (2) Mendeskripsikan faktor yang menyebabkan campur kode dalam novel 99 Cahaya di Langit Eropa karya Hanum Salsabiela Rais dan Rangga Almahendra.

Sosiolinguistik memandang bahasa sebagai tingkah laku sosial yang dipakai dalam komunikasi [7]. Oleh sebab itu, sebagai makhluk sosial dan berbudaya, bahasa tidak pernah terlepas dari kegiatan manusia. Fungsi bahasa dalam masyarakat berbudaya yaitu untuk berinteraksi, bekerja sama, dan mengidentifikasi diri. Dengan demikian, dalam pengkajian bahasa tidak bisa terlepas dari penggunaan bahasa di masyarakat.Sosiolinguistik merupakan kajian bahasa dalam pemakaian yang tujuannya untuk menunjukkan kesepakatan atau kaidah-kaidah penggunaan bahasa (yang disepakati oleh masyarakat), dikaitkan dengan aspek-aspek kebudayaan dalam masyarakat itu [9]. Dalam sosiolinguistik ini dibicarakan mengenai pemakai dan pemakaian bahasa, tempat pemakaian bahasa, tata tingkat bahasa, perlbagai akibat adanya kontak dua bahasa atau lebih, dan ragam serta waktu pemakaian ragam bahasa itu [1]. Sosiolinguistik merupakan kajian tentang bahasa yang berkaitan dengan kondisi kemasyarakatan.

Istilah bilingualisme dalam bahasa Indonesia disebut juga dwibahasaan. Bilingualisme merupakan penggunaan dua bahasa atau lebih oleh seseorang atau oleh suatu masyarakat [3]. Sejalan dengan itu, bilingualisme diartikan sebagai penggunaan dua bahasa oleh seorang penutur dalam pergaulannya dengan orang lain secara bergantian [2]. Penutur yang menggunakan dua bahasa dalam berkomunikasi disebut dwibahasawan, sedangkan kemampuan dalam menggunakan dua bahasa disebut bilingualitas. Kedwibahasaan adalah gejala penguasaan bahasa kedua dengan derajat kemampuan yang sama seperti penutur aslinya [7]. Namun, pada kenyataannya tidak semua orang dapat menguasai bahasa kedua (B2) dengan sempurna atau setara dengan bahasa pertama (B1). Dwibahasaan mengacu kepada pemilikan kemampuan atas sekurangkurangnya bahasa ibu dan bahasa kedua meskipun kemampuannya atas bahasa kedua kedua itu hanya sampai batas yang minimum [7]. Dengan demikian, dapat disimpulkan bahwa bilingualisme bisa terjadi pada penutur yang berkemampuan mempunyai dua bahasa secara berganti-gantian walaupun penguasaan bahasa kedua sangat rendah.

Campur kode adalah jika dua unsur bahasa, biasanya berupa leksikon atau deretan leksikon yangdigunakan secara bersama-sama dalam satu interaksi komunikasi[10]. Campur kode terjadi apabila ada sebuah kode utama yang digunakan dan memiliki fungsi dan keotonomiannya kemudian disisipi dengan kode-kode yang lain tanpa fungsi sebagai sebuah kode[2]. Campur kode merupakan satu di antara aspek dari saling ketergantungan bahasa di dalam masyarakat multilingual yang secara mutlak murni tanpa sedikitpun memanfaatkan bahasa atau unsur bahasa lain [7]. Dari beberapa pendapat ahli, maka dapat disimpulkan bahwa campur kode merupakan kegiatan komunikasi yang dilakukan oleh dua orang atau lebih dengan menggunakan dua unsur bahasa dalam waktu bersamaan.

Campur kode dibagi menjadi dua bentuk yaitu campur kode ke dalam (inner code-mixing), campur kode keluar (outer code-mixing), dan campur kode campuran[6]. Wujud campur kode dapat berupa penyisipan kata, frasa, klausa, penyisipan ungkapan atau idiom, penyisipan perulangan kata, dan penyisipan baster [8].

Teori yang digunakan untuk membahas faktor-faktor penyebab terjadinya campur kode dilihat dari komponen tutur. Komponen tutur Hymes [2] yang menyebabkan terjadinya campur kode diakronimkan menjadi SPEAKING (setting and scene, participants, ends, act sequences, key, instrumentalities, norms, and genre).

\section{METODE}

Metode penelitian yang digunakan adalah metode deskriptif. Bentuk penelitian yang digunakan adalah pendekatan kualitatif, yaitu prosedur penelitian yang menghasilkan data deskriptif berupa kata-kata tertulis atau lisan dari orang-orang dan perilaku yang dapat diamati [4]. Pendekatan yang digunakan dalam penelitian ini adalah pendekatan sosiolinguistik.

Sumber data dalam penelitian ini adalah dialog yang berupa kata, frasa, baster, pengulangan kata, idiom, dan klausa pada novel 99 Cahaya Di Langit Eropa (Perjalanan Menapak Jejak Islam di Eropa). Teknik yang digunakan dalam pengumpulan data dalam penelitian ini adalah teknik langsung, artinya peneliti membaca dan mengamati langsung novel yang diteliti.

Alat pengumpul data yang digunakan adalah peneliti sendiri sebagai instrumen kunci dan dibantu kartu pencatat data. Peneliti sebagai perencana, pelaksana pengumpul data, analisis data, dan pada akhirnya menjadi pelapor dari hasil penelitian yang dilakukan.

\section{HASIL DAN PEMBAHASAN}

Analisis data merupakan langkah selanjutnya dalam penelitian ini. Data yang sudah dipilah-pilah menurut aspek kebahasaan yang terkandung dalam novel 99 Cahaya di Langit Eropa akan dianalisis sebagai berikut.

1. Aspek kebahasaan yang terkandung dalam novel 99 Cahaya di Langit Eropa

a. Penyisipan Unsur-unsur yang Berwujud Kata

Pada novel 99 Cahaya di Langit Eropa terdapat penyisipan unsur yang berwujud kata sebanyak 37 buah yang terdiri dari bahasa Inggris berjumlah 23 buah, bahasa Jawa berjumlah 6 buah, bahasa Jerman berjumlah 9 buah. Penyisipan unsur berwujud kata dapat dicontohkan sebagai berikut.

Sudah terlalu banyak buku travelingsebelumnya, terutama tentang Eropa dan segala keindahannya, yang hadir.

Pada dialog tersebut disisipi kata traveling. Kata traveling yang mempunyai arti berlibur. Kata ini berkedudukan sebagai kata kerja. Traveling disebut sebagai kata karena traveling merupakan satuan gramatikal terkecil 
dan dapat diujarkan sebagai bentuk bebas. Peristiwa campur kode tersebut termasuk dalam jenis campur kode ke luar.

Umat islam terdahulu adalah "traveller" yang tangguh.

Pada kalimat tersebut disisipi kata traveller atau dalam bahasa Indonesia yang artinya wisatawan. Kata traveller dalam konteks bahasa Indonesia mempunyai kedudukan sebagai kata benda. Peristiwa campur kode tersebut termasuk dalam jenis campur kode ke luar.

Sesuai namanya, Kahlenberg, “Kahl” dalam bahasa Jerman berarti telanjang, sementara “berg” pegunungan.

Selanjutnya disisipi kata kahl dan berg. Kata kahl yang berarti telanjang dan dalam konteks bahasa Indonesia dikategorikan sebagai kata sifat dan berg yang berarti pegunungan, dalam konteks bahasa Indonesia dikategorikan kata benda, peristiwa campur kode tersebut termasuk dalam jenis campur kode ke luar.

b. Penyisipan Unsur-unsur yang Berwujud Frasa

Frasa merupakan satuan gramatika yang terdiri dari dua kata atau lebih yang tidak terdiri dari subjek dan predikat. Berdasarkan analisis data, novel 99 Cahaya di Langit Eropa terdapat penyisipan unsur yang berwujud frasa sebanyak 10 buah yang terdiri dari bahasa Inggris berjumlah 9 buah, bahasa Arab berjumlah 1 buah. Penyisipan berwujud frasa yang berasal dari bahasa Inggris dan bahasa Arab. Contoh penyisipan berwujud frasa sebagai berikut.

1) Disebelahnya Aye justru dengan tenag menyantap

Butter croissant keju pilihannya.

2) Daging babi sudah pasti absen karena tidak lulus ujian "Halal Food" yang ditulis besarbesar di dinding warung.

3) Dia seperti haqqul yaqin, kerajaannya akan tumbuh luas dan besar meski dia sudah ditelan bumi.

Pada nomor 1 terdapat kalimat yang disisipi frasa butter croissant merupakan nama sebuah roti yang biasa dikonsumsi oleh masyarakat Austria. Frasa ini tergolong frasa nomina. Pada nomor 2 disisipi frasa halal food yang artinya makanan yang halal. Frasa halal food berasal dari bahasa Arab dan bahasa Inggris. Frasa halal food tergolong frasa nomina. Pada nomor 3 disisipi frasa haqqul yaqin berasal dari bahasa Arab yang artinya sangat yakin. Frasa haqqul yaqin tergolong frasa adjektiva. Peristiwa campur kode di atas tersebut termasuk dalam jenis campur kode ke luar.

c. Penyisipan Unsur-unsur yang Berwujud Baster

Baster merupakan perpaduan dua unsur bahasa yang berbeda, membentuk satu makna. Pada novel 99 Cahaya di Langit Eropa unsur yang berwujud baster sebanyak 5 buah yang terdiri dari bahasa Inggris berjumlah 5 buah. Penyisipan berwujud baster dapat dipaparkan sebagai berikut.

Karena sehelai kain penutup tempurung kepala yang tampak dalam pas foto curriculum vitae-nya, dia tertolak untuk bekerja secara profesional.
Kalimat di atas disisipi baster curriculum vitae-nya yang artinya adalah biodata, curriculum vitae merupakan kata benda.

Dia segera menghabiskan green tea-nya, lalu memanggil pelayan perempuan yang siap sedia menerima panggilan pesanan maupun pembayaran dari pelanggan.

Kalimat di atas disisipi baster green tea-nya. Baster greentea-nya merupakan sebutan untuk sebuah minuman yang terbuat dari daun teh. Baster green tea merupakan kata benda.

Aku lupa siapa namanya, tapi dia sudah memenggal ribuan orang dengan guillotine-nya.

Kalimat di atas disisipi baster guillotine-nya, kata guillotine merupakan sebutan alat yang digunakan untuk memenggal kepala dan tergolong kata benda.

Kan hati dan perasaan orang yang ber-sun bathing di rerumputan Danube?

Kalimat di atas disisipi baster ber-sun bathing yang artinya adalah berjemur. Kata ber-sun bathing tergolong kata kerja.

.... karena aku tak tahu kapan aku bisa membalas 'treat'-nya.

Kalimat di atas disisipi kata treat-nya yang artinya adalah perlakuan. Kata treat-nya tergolong kata kerja. Peristiwa campur kode yang berwujud penyisipan baster termasuk dalam jenis campur kode ke luar.

d. Penyisipan Unsur-unsur yang Berwujud Pengulangan Kata

Perulangan kata ialah kata yang mengalami perulangan baik seluruhnya maupun sebagian, baik yang bervariasi fonem maupun tidak. Berdasarkan analisis data, novel 99 Cahaya di Langit Eropa terdapat penyisipan unsur yang berwujud perulangan kata sebanyak 7 buah terdiri dari bahasa daerah. Penyisipan unsur berwujud perulangan kata dapat dipaparkan sebagai berikut.

Ayse yang terus berada dalam pelukanku sesekali kubiarkan mencoba memencet-mencet tombol capture.

Kalimat di atas disisipi perulangan kata memencetmencet berasal dari kata pencet yang ditambahkan dengan imbuhan me- sehingga huruf depan menjadi luluh dan mengalami pengulangan kata. Kata memencet-mencet bermakna menekan keras-keras (dengan ibu jari dan sebagainya), kata memencet-mencet tergolong kata kerja, dan termasuk jenis campur kode ke dalam.

Kerlap-kerlip keemasan terpancar dari jutaan lampu gedung, rumah-rumah dan mobil yang lalu-lalang.

Kalimat di atas disisipi pengulangan kata kerlapkerlip yang bermakna berkilauan dan kata lalu-lalang yang bermakna berjalan berkali-kali secara tidak teratur.Kata kerlap-kerlip, lalu-lalang tergolong pengulangan kata dengan variasi fonem dan merupakan kata kerja. Peristiwa campur kode tersebut termasuk dalam jenis campur kode ke dalam.

Semuanya begitu terstruktur, tidak morat-marit. 
Pada kalimat di atas disisipi pengulangan kata bervariasi fonem morat-marit yang artinya adalah porakporanda, berantakan. Kata morat-marit tergolong kata sifat dan peristiwa campur kode tersebut termasuk dalam jenis campur kode ke dalam.

e. Penyisipan Unsur-unsur yang Berwujud Idiom

Ungkapan atau idiom adalah gabungan kata yang maknanya tidak sama dengan gabungan makna anggotanya. Pada novel 99 Cahaya di Langit Eropa terdapat penyisipan unsur yang berwujud idiom sebanyak 2 buah yang terdiri dari bahasa Inggris.

Aku juga tak perlu membaca kutipan kata-kata wisdom of life para tweep dan facebooker.

Pada kalimat di atas terdapat penyisipan idiom wisdom of life yang artinya adalah kebijaksanaan hidup. Ungkapan ini terdiri dari dua kata yaitu wisdom berarti kebijaksanaan dan life berarti kehidupan.

\section{Take and give}

Terdapat penyisipan ungkapan take and give yang berarti memberi dan menerima. Idiom take and give untuk mengungkapkan konsep tentang ihklas.Peristiwa campur kode yang berupa penyisipan idiom tersebut termasuk dalam jenis campur kode ke luar.

f. Penyisipan Unsur-unsur yang Berwujud Klausa

Klausa merupakan satuan gramatikal unsur pembentuk kalimat yang berstruktur predikatif. Pada novel 99 Cahaya di Langit Eropa terdapat penyisipan unsur yang berwujud klausa sebanyak 12 buah. Penyisipan unsur yang berwujud klausa dapat dipaparkan sebagai berikut.

"Ich mag Milka gern. Aber...danke, Ich faste. Saya sangat suka cokelat Milka. Tapi...terima kasih, saya sedang berpuasa," jawab Fatma santun.

Terdapat penyisipan klausa "Ich mag Milka gern. Aber...danke, Ich faste"yang artinya "Saya sangat suka cokelat Milka. Tapi...terima kasih, saya sedang berpuasa". Penyisipan klausa di atas merupakan bagian dari kalimat majemuk bertingkat. Kata Ich yang berarti saya berfungsi sebagai subjek dan danke yang berarti sedang berpuasa yang berfungsi sebai predikat. Makna dari klausa tersebut menyatakan bahwa lawan tutur sedang berpuasa.

"If you want to ridicule Muslims, this is how to do it! Kalau kalian mau mengolok-ngolok Muslim, begini caranya!"

Terdapat penyisipan klausa If you want to ridicule Muslims, this is how to do it!, yang artinya adalah "kalau kalian mau mengolok-ngolok Muslim, begini caranya!". Kata if you berfungsi sebagai subjek, want to ridicule berfungsi sebagai predikat, kata muslims berfungsi sebagai objek, dan kata this is how to do it berfungsi sebagai pelengkap.

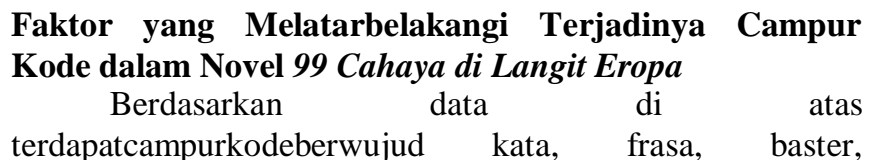
pengulangan kata, idiom, dan klausa.Faktor yang melatarbelakangi campur kode pada tuturan antar tokoh di atas adalah karena kebiasaan penutur dan mitra tutur menggunakan bahasa Inggris, bahasa Jerman, dan bahasa Daerah dalamkehidupansehari-hari dan latar belakang tokoh yang berasal dari negara yang berbeda. Gambaran yang jelasmengenai faktor yang melatarbelakangi campur kode dalam novel 99 Cahaya di Langit Eropa dapat dipahami dengan analisis delapan komponen tuturSPEAKING sebagai berikut.

a) Setting dan scene berhubungan dengan latar tempat peristiwa tutur terjadi berkaitan dengan tempat (where) dan waktu (when) dansuasanabicara. Tuturan pada data di atas dilakukan di lingkungan kampus, di lingkungan rumah/kost tokoh, padawaktusiang, malam, pagi tepatnya pada saat proses berinteraksi antar tokoh berlangsung. Suasana dalam tuturan diatas sifatnya formal dan nonformal.

b) Participant smelingkupi penutur, mitratutur, danpendengar yang terlibatdalamsuatu interaksi. Penuturdanmitratutur yang terlibatdalamperistiwatutur di atasseorang Rangga yang berasal dari Indonesia sebagai tokoh utama yang mengenyam pendidikan tinggi di Jerman, Hanum yang merupakan istri dari Rangga yang kesehariannya menggunakan bahasa Indonesia dengan suaminya. Stefan merupakan teman dari Rangga yang berasal dari Jerman, Khan merupakan tokoh yang berasal dari Pakistan, Fatma dan Ayse yang berasal dari Turki. Marion merupakan seorang muallaf yang berasal dari Prancis. Maarja berasal dari Jerman.

c) End mengacu pada maksud dan tujuan pertuturan. Peristiwa tutur di atas, membicarakan masalah yang berkaitan dengan kehidupan sehari-hari antar tokoh.

d) Act sequences berhubungan dengan bentuk (form) dan isi (content) suatu tuturan. Peristiwa tutur di atas menggunakan kode bahasa Inggris,bahasa Jerman, dan bahasa Indonesia dengan ragam formal yang sudah bercampur dengan kode bahasa lain.

e) Key berhubungan dengan sikap, cara, nada suara, serta penjiwaan saat sebuah tuturan diucapkan. Komunikasi antara seorang tokoh dan tokoh lainnya merupakan komunikasi yang bersifat horizontal karena mempunyai kedudukan yang sama sehingga sikap yang ditunjukkan penutur terhadap mitra tutur adalah sikap yang tegas sehingga mitra tutur menjawab dengan nada.

f) Instrumentalities berkaitan dengan alat yang digunakan dalam tuturan. Peristiwa tutur di atas merupakan bentuk tuturan berhadapan langsung atau oral. Sedangkan bahasa yang digunakan adalah bahasa Inggris, bahasa Jerman, dan bahasa Indonesia.

g) Norms berkaitan dengan norma interaksi dan norma interpretasi. Dalamperistiw atutur di atas disampaikan secara sopan dan agak sedikitk aku terutama bahasa yang dipakai oleh mitra tutur.

h) Genre berkaitan dengan jenis tuturan yang digunakan. Peristiwa tutur di atas disampaikan dengan dialog secara lisan antara penutur dan mitra tutur.

IV. SIMPULAN DAN SARAN 


\section{SIMPULAN}

Berdasarkan hasil penelitian dan pembahasan mengenai Campur Kode dalam Novel 99 Cahaya di Langit Eropa, dapat disimpulkan beberapa hal sebagai berikut.

1. Hasil analisis menunjukkan terjadinya campur kode berwujud penyisipan kata, penyisipan frasa, penyisipan baster, penyisipan pengulangan kata, penyisipan idiom, dan penyisipan klausa.

2. Hasil analisis juga menunjukkan bahwa novel 99 Cahaya di Langit Eropa terdapat dua bentukcampurkode yaitu campur kode kedalam (intern), dancampurkodekeluar (ekstern).

3. Terjadinyacampurkodedisebabkanolehbeberapafaktor diantaranyatempat dan waktu terjadinya sebuah tuturan (settings), peserta tutur menunjuk kepada minimal dua pihak dalam bertutur (participants), tujuan dari suatu peristiwa dalam suatu masyarakat (ends), pokok tuturan (act sequences), nada tutur menunjuk pada nada, cara, dan motivasi di mana suatu tindakan dapat dilakukan dalam bertutur (keys), sarana tutur menunjuk kepada saluran tutur dan bentuk tutur (instrumentalities), norma tutur (norms), dan jenis tutur menunjuk kepada jenis kategori kebahasaan yang sedang dituturkan (genre).

\section{SARAN}

Penelitian ini diharapkan dapat menjadi referensi bagi penelitian selanjutnya dalam bidang sosiolinguistik, khususnya kajian mengenai campur kode dalam karya sastra.

\section{DAFTAR PUSTAKA}

[1] Chaer, Abdul. 2012. Linguistik Umum. Jakarta: PT Rineka Cipta

[2] Chaer, Abdul \& Leoni Agustina.2010. Sosiolinguistik Perkenalan Awal. Jakarta: Rineka Cipta.

[3] Kridalaksana, Harimurti. 2001. Kamus Linguistik. Jakarta: Gramedia Pustaka Utama.

[4] Moleong, Lexy J. 2008. Metodologi Penelitian Kualitatif (Edisi Revisi). Bandung: PT Remaja Rosdakarya.

[5] Rais, Hanum Salsabiela \& Rangga Almahendra. 2013. 99 Cahaya di Langit Eropa (Perjalanan Menapak Jejak Islam di Eropa). Jakarta: PT Gramedia Pustaka Utama.

[6] Rohmani, Siti. 2012. "Analisis Alih Kode dan Campur Kode Novel Negeri 5 Negara Karya Ahmad Fuad”. PBS FKIP UNS (lib.uns.ac.id).

[7] Saddhono, Kundharu. 2012. Pengantar Sosiolinguistik Teori dan Konsep. Surakarta: Sebelas Maret University Press.

[8] Saddhono, Kundharu. 2013. Pengantar Sosiolinguistik Teori dan Konsep. Surakarta: Sebelas Maret University Press.

[9] Sumarsono. 2013. Sosiolinguistik. Yogyakarta: SABDA.

[10] Waluyo, Herman J. 2008. Sosiolinguistik. Surakarta: Universitas Sebelas Maret. 